\title{
EAST CENTRAL EUROPE \\ IN THE CONTEXT OF THE VARIETIES \\ OF CAPITALISM APPROACH
}

ABSTRACT The article presents the Varieties of Capitalism theory proposed by Peter A. Hall and David Soskice in 2001 and its applicability in the context of East Central Europe's economies. Apart from the concepts of Liberal and Coordinated Market Economies created by Hall and Soskice, the article introduces the development of the theory made by scientists such as Bruno Amable or Andreas Nölke and Arjan Vliegenthart, focusing on the Post-Communist countries. Also, it refers to Dorothee Bohle and Béla Greskovits' critique of the theory in an attempt to outline the constant evolution of this relatively fresh idea.

KEYWORDS Varieties of Capitalism (VoC), Liberal Market Economy (LME), Coordinated Market Economy (CML), Dependent Market Economy (DME), East Central Europe

\section{INTRODUCTION}

To understand the rapidly changing world it is essential to carefully observe upcoming alterations. It is even more important when one attempts to create theories in the social sciences. As Sławomir Sztaba notices, the subject of economy and other social sciences is changing so quickly that the theories require constant adjusting ${ }^{1}$. Capitalism, defined by Sztaba as a social-economic system based on private property, individual freedom of entering agreements as well as entrepreneurship and competitiveness, is also considered

\footnotetext{
S. Sztaba, "Ewolucja kapitalizmu i teorii ekonomii", in J. Osiński (ed.), Kapitalizm czy kapitalizmy? Anatomia i ewolucja formacji, Warszawa 2012, p. 12.
} 
by him to be a system that is the most open for evolution (revolution, even) and innovation $^{2}$. Yet as it is not hard to find different views on capitalism, this term seems to be complicated, if not confusing. Jerzy Wilkin in his book Jaki kapitalizm, jaka Polska? [What kind of capitalism, what kind of Poland?] poses a question whether there is just one capitalism or as many of them as there are capitalist countries? ${ }^{3}$ Wilkin provides us with another definition of this term: in addition to being a market economy, it is also a political system, a social structure and a dominant cultural model. As the boundaries between these elements seem blurred, the natural conclusion is that capitalism varies among different market economies according to their cultural and historical backgrounds ${ }^{4}$. If we consider this to be true, then the division into Western Europe and Communist countries during the Cold War, the fall of the Soviet Union as well as the transition to market economy and democracy in most of the countries behind the Iron Curtain must have resulted in some major differences in development level and democratic institutions.

The theoretical approach that Hall and Soskice introduced in 2001 regarding comparative capitalism in their work - Varieties of Capitalism. The Institutional Foundations of Comparative Advantage - though it has already been in development for more than ten years, is still quite recent. Interpretation in the national context, reevaluation and critique of the theory are ongoing processes and it seems that the subject requires further analysis. One of the main criticisms of this approach is that it takes into consideration only a few developed states, like the United States, Germany or Japan, and makes an assumption that the results are adequate with respect to all capitalist economies.

Because the first ideas of Liberal and Coordinated Market Economies (LME, CME) seemed to be insufficient for many scholars, new ideas that could better suit economic systems in different parts of the world were created. Academics focused on the issues in East Central Europe - where the transition from communism to capitalism happened a little more than 20 years ago - first introduced the idea of the mix of Liberal and Coordinated Market Economies 5 . Yet further analysis showed that the economies of East Central Europe should be considered to be a model themselves, and so they were classified as Dependent Market Economies (DME) ${ }^{6}$. Later this approach was also considered to be a narrow view of the divided area. Smaller groups of countries

\footnotetext{
Ibid., p. 14.

J. Wilkin, Jaki kapitalizm, jaka Polska?, Warszawa 1995, p. 21.

4 Ibid., pp. 21-23.

5 D. Lane, "Post-State Socialism: A Diversity of Capitalism?", in M. Myant, D. Lane (eds.), Varieties of Capitalism in Post-Communist Countries, Basingstoke-New York 2007, pp. 13-62; V. Mykhnenko, "Poland and Ukraine: Institutional Structures and Economic Performance", in M. Myant, D. Lane (eds.), Varieties of Capitalism..., pp. 124-145; A. Török, "Newcomers in the Developed World? Notes on the Varieties of Capitalism in the New Member States of the European Union", International Journal of Business Insights and Transformations, vol. 5, no. 3 (2012).
}

6 A. Nölke, A. Vliegenthart, "Enlarging the Varieties of Capitalism: The Emergence of Dependent Market Economies in East Central Europe”, World Politics, vol. 61, no. 4 (2009), pp. 670-671, [online] http://dx.doi.org/10.1017/S0043887109990098. 
in the region had separately dealt with the transformation and therefore some scholars proposed new ideas on how to describe the forms of capitalism created in the Post-Communist states?

Currently, the number of publications dealing with the subject of East Central Europe in the context of Varieties of Capitalism ( $\mathrm{VoC}$ ) is steadily rising. Each scholar, having found previous theories to be insufficient, attempts to create one of his own, with different variables. In effect, we are left with a growing number of publications that, instead of making the issue clear and understandable, introduce even more controversies. Since the political and economic situation in the countries differs from region to region, it is self-evident that the implemented capitalism would have also proceeded differently. In this paper I would like to find out which of the approaches best suits East Central Europe as far as the Varieties of Capitalism theory is concerned. In order to do that, I will present the development of the theory, from its very beginning to the introduction of more complex approaches, with special emphasis on the specific patterns concerning East Central Europe.

\section{VARIETIES OF CAPITALISM - THE THEORY AND FIRST DEVELOPMENT}

Establishing the idea of Varieties of Capitalism was seen by Hall and Soskice as an answer to the insufficiency of approaches which dominated the comparative study of capitalism. As those scholars argued, the particular perspectives developed to address concrete problems, while accurate in the time of their formulation, recently became insufficient. As global capitalism develops, ideas also have to change to suit the problems which the contemporary world is currently facing ${ }^{8}$.

The first perspective the academics were referring to was the modernization approach, created in 1965 as a criticism of the pre-war policies in industries run by states to protect their growth rate. Hall and Soskice argue that the strength of the country could have been an obstacle instead of an asset in the improvement of its economic status. The idea of neo-corporatism was introduced to comparative capitalism in 1970, when academics tried to respond to the problem of overflowing inflation. This approach, describing the role of the state as a negotiator between employers and the labor movement, was stressing the benefits of this network for every actor. Here the scholars' critique is based on the neglect of the companies' role in the development of economic growth. The last approach the scholars addressed came to life between 1980s and 1990 s and focused on the behaviors of companies. The approach of a social system of production was concerned with the shift from mass production to a new model of production organization, based on external institutions organized collectively on all levels

D. Bohle, B. Greskovits, Capitalist Diversity on Europe's Periphery, Ithaca 2012.

$8 \quad$ P. Hall, D. Soskice, "An Introduction" in P. Hall, D. Soskice (eds.), Varieties of Capitalism. The Institutional Foundations of Comparative Advantage, Oxford 2001, p. 2. 
- local, regional and national. Hall and Soskice point out that the framework of those institutions is linked to the state policy, while in their eyes it is more important to differentiate between countries instead of focusing so much on the lower levels of the organizational framework? .

Another thing Hall and Soskice notice are the relations between economic behavior and political economy. They present three main approaches that dominate the discipline, the first of which is the idea of socializing agencies that instill a particular set of norms or attitudes in those who operate within them. The other concept they are introducing concerns the effects of an institution follow from the power it confers on particular actors through the formal sanctions that hierarchy supplies or the resources an institution provides for mobilization. Institutions conceived as a matrix of sanctions and incentives hold the idea that the framework created by them organizes the behavior of the actors and makes it predictable. What Hall and Soskice find missing in those approaches is the strategic interactions of the actors in political economy, which are usually neglected in the discipline of comparative capitalism ${ }^{10}$.

\subsection{The center of the Varieties of Capitalism theory}

Hall and Soskice regard companies as the crucial actors in a capitalist economy. They argue that the companies are the main catalyst of change in the economic system in terms of implementing new technologies and challenges in the international trade and competition policy. The main aspect of a firm's actions is in fact the coordination of its connections with other actors, both external and internal. This means that the very existence and prosperity of the company relies on the relations between the firm and its own employees, as well as other companies, clients, suppliers, trade unions or governments. The success of companies as actors in political economy is related to the effectiveness of their relations with other actors. The scholars argue that while facing many obstacles in encountering different actors, the company may suffer difficulties in coordinating those relations ${ }^{11}$.

The authors focus on an analysis of the five levels of connection. Industrial relations are mentioned first. They concern the relations between the company and their labor force in terms of wage and working conditions. The issue of providing workers with sufficient skills and abilities, as well as investments made by the employees themselves, is addressed by the sphere of vocational training and education. The aspect of corporate governance is related to seeking and securing funding provided by investors. It also includes the investors' requirement of assuring their incomes. The Inter-firm relations, on the other hand, concern the relations between the firm and its suppliers, clients and other companies - which include issues related to proper resources, outcomes of production process or technology development. The last sphere, employees, is seen as a re-

\footnotetext{
9 Ibid., pp. 3-4.

10 Ibid., p. 5.

11 Ibid., p. 6.
} 
lation which the company is supposed to create with its workforce to make sure that they are heading in the right direction. Following the way in which the national political economies address all those elements or, to quote Pavol Babošs words: depending on the mode of coordination, either strategic or competitive ${ }^{12}$ - the authors establish two types of political economies ${ }^{13}$, the Liberal Market Economy and the Coordinated Market Economy ${ }^{14}$.

\subsection{Liberal Market Economy and Coordinated Market Economy}

The authors believe that each state falls into one of the categories according to the institutional support that it provides for the actors. In their opinion enterprises are establishing their policies according to the framework they are given. That is why if companies in a particular country generally resolve their problems in the spheres listed above by hierarchical solutions and competitive market arrangements, the economy of the country is considered to be the Liberal Market Economy. The exchange of goods and supplies follows formal contracting and competition. That kind of equilibrium is usually achieved through the balance between the situation in a competitive market and the response of the company, while taking into consideration the affordability of resources and the demand. The Coordinated Market Economy, on the other hand, means that companies rely on non-market connections, like collaborative relationships, informal monitoring of network and informal contracting. The company in CME achieves equilibrium thanks to the strategic relations of the actors in political economy ${ }^{15}$.

Because the authors define institutions as a set of formal or informal rules that create a framework which actors generally follow, they also recognize the market as an institution which provides support for a particular type of relationship between actors. In Liberal Market Economies the legal system and hierarchy provide support which helps to resolve the problems that the enterprises are facing. Although the Coordinated Market Economies also include the ideas of hierarchy and market, institutions are supported mostly by the strategies of companies that secure the relationships between actors and the expectation of high returns. Therefore, they usually need the exchange of information between companies and other actors, the monitoring of their behavior and the sanctioning of withdrawal from their commitment ${ }^{16}$.

12 P. Baboš, "Varieties of Capitalism in Central and Eastern Europe: Measuring the Co-ordination Index of a National Economy”, SEER Journal for Labour and Social Affairs in Eastern Europe, no. 4 (2010), p. 443.

13 Among the precursors of this approach we should mention Gøsta Esping-Andersen and the work The Three Worlds of the Welfare Capitalism, Michel Albert and his Kapitalizm kontra kapitalizm, as well as a non-economic classification of capitalism Siedem kultur kapitalizmu written by Charles Hampden-Turner and Alfonsus Trompenaars.

14 P. Hall, D. Soskice, “An Introduction”..., pp. 7-8; J. Gładys-Jakóbik, "Kryzys kapitalizmu, wartości etycznych czy współczesnej kultury?”, in. J. Osiński (ed.), Kapitalizm czy kapitalizmy?..., pp. 45-46.

15 P. Hall, D. Soskice, “An Introduction”..., pp. 8-9.

16 Ibid., pp. 9-10. 
According to the authors, the United States, Great Britain, Australia, Canada, New Zealand and Ireland are the closest to Liberal Market Economies, while Coordinated Market Economies include Germany, Japan, Switzerland, Belgium, Sweden, Norway, Denmark, Finland and Austria. Because there were six countries that could not fit into those groups, for France, Italy, Spain, Portugal, Greece and Turkey an additional model, called the Mediterranean (or Mixed) Model, have been created. Its main characteristics are non-market coordination in the area of enterprises' finances, caused by relatively strong agricultural sector, and state interventionism. On the other hand it is also liberal in terms of labor work regulations ${ }^{17}$

An interesting point of the authors' theory is the notion of historical aspects of political economies. Hall and Soskice emphasize that the institutions are not built at once and their effectiveness is not constant, but implies perpetual engagement of all actors and their experience in the given field. The history of the country as well as expectations of the institutions and the actors shape the national political economy, and it is important to understand its development ${ }^{18}$.

\subsection{Development of the theory - five categories of capitalism}

Because some scholars found this typology based on the coordination processes of companies insufficient, new ideas were introduced to the Varieties of Capitalism approach. One of those was put forward by Bruno Amable whose analysis of capitalism is based not on the company as a central actor, but on the institutional areas which he finds fundamental: product-market competition, wage-labor and labor-market institutions, the financial intermediation sector and corporate governance, social protection and welfare state, as well as education ${ }^{19}$.

Taking into consideration different institutional forms and complementarities, Amable proposes five categories of capitalism. The first one, a market-based model, is the only one not established on the geography-based denomination, but follows Hall and Soskice's idea of LME, where the government does not interfere with the economy and the network of social services is considered loose $\mathrm{e}^{20}$. The rest of them are social-democratic, Continental European, Mediterranean, and Asian and refer to a specific region, although as the author stresses, the aim is to simplify and clarify rather than to distinguish a cultural or any other difference ${ }^{21}$.

The social-democratic system, which represents the Nordic countries with a high level of social security, is characterized by general retraining of labor force and strong economic competitiveness. Central Europe - Germany and Austria - are classified as the Continental European model. It is similar to the social-democratic one, especially in

\footnotetext{
17 J. Gładys-Jakóbik, “Kryzys”..., pp. 46-47.

18 P. Hall, D. Soskice, “An Introduction”..., pp. 13-14.

19 B. Amable, Diversity of Modern Capitalism, Oxford-New York 2004, p. 14.

20 A. Török, "Newcomers"..., p. 6.

$21 \quad$ B. Amable, "Diversity”..., p. 14.
} 
terms of competitiveness and government involvement, but the welfare state is not that developed. Low protection of labor rights distinguishes this model from the following one. In the Mediterranean system the labor force is significantly better developed. The overgrown bureaucracy, characteristic of such countries as Greece, Portugal, Italy and Spain, impedes their economic growth. The last variant, the Asian one, refers to the dependency of business on the relationship between companies, the state, and the financial system with the low social security, moved from the state's responsibility into family ties. The labor force has the opportunity to retrain and transfer into different corporations ${ }^{22}$.

According to Mykhnenko's survey, the Polish capitalism can be described as both mixed and coordinated market economy - if we look at Hall and Soskice's typology - or Mediterranean or Asian type according to the categories created by Amable. That classification is based on regulation of product markets and the law allowing the government to be involved in economic processes. Also very important in this case is the high level of bureaucracy hindering the activities of companies, protectionism of trade and investments as well as non-market coordination of economic actors ${ }^{23}$. Yet the question is whether the $\mathrm{VoC}$ in the form described above can be actually applied to Poland or any other country in East Central Europe, not to mention the entire Post-Communist world. Scholars have not focused on the developed countries without a reason. Western economies are considered to be old, well-established and stable. It means that societies have traditions of functioning in free market systems with all their advantages and disadvantages. With that kind of assumption, a theory set only on the activities of the company or selected institutional areas might seem sufficient. But the countries in transition (still 'developing' in comparison to the 'developed'), without a strong background of capitalist culture, need a different approach suited to their situations. A similar conclusion can be found in Baboš research on the level of stock market capitalization in USA, Germany, Estonia and Slovenia ${ }^{24}$. Although the ECE countries along with Germany have a lower stock capitalization level than the United States, the theory ignores the region's specific conditions and thus cannot be fully applicable.

\section{THE SPECIFICITY OF TRANSFORMATION IN POST-COMMUNIST COUNTRIES}

A little more than twenty years passed since the Soviet Union had collapsed, and despite the fact that most of Eastern Europe's former Soviet satellites have gained European Union membership, there are still many distinctions between Eastern and Western Europe. In fact, as Dorothy Bohle and Bela Greskovits notice in their publication Capitalist Diversity on Europe's Periphery, scholars were eager to stress that capitalism

\footnotetext{
22 D. Lane, "Post-State Socialism”..., pp. 18-19, A. Török, "Newcomers"..., p. 6.

23 V. Mykhnenko, "Poland and Ukraine”..., p. 126.

24 P. Baboš, “Varieties”..., p. 451.
} 
in East Central Europe was very unstable from the start. The reasons for that were, for instance, fast transformations or partial reforms creating confusions and unclear institution $s^{25}$. We cannot forget, though, that among the Post-Communist countries there are those which, while not a part of the EU, introduced the capitalist system with better results than others. Moreover, there still are countries that are far behind on their way to free market and capitalism. While developing the Varieties of Capitalism approach, many scholars realized that the specificity of the Post-Communist political economies calls for a different category, or even - more categories, since particular groups of states tended to use similar strategies when coping with the transformation and its outcomes.

David Lane starts his paper on the Post-Communist countries by noting that changes which happened at the beginning of the 90 s were not consequences of any kind of economic revolution. The main part of the reforms was the political transition to democracy and the establishment of civil society, and the idea of capitalism was mostly implemented as a step toward further democratization ${ }^{26}$. The political leaders were trying to introduce the neoliberal version of capitalism following the Anglo-American model which, as Bohle and Greskovits argue, was impossible to implement prior to overcoming many obstacles ${ }^{27}$. In comparison to the countries which achieved the current level of capitalism after the bourgeois and private ownership, which were the social basis for democratic pluralism in other countries, in Communist states it was the government who was the owner of goods and was coordinating the free market and the economic relations between actors. And as Lane admits, the typography established for the Varieties of Capitalism approach is not sufficient for countries undergoing transformation ${ }^{28}$.

Lane is convinced that although the industry in socialist countries was not effective enough to catch up with the capitalist ones, they had good industrial foundation and well-developed human resources. However, his beliefs that standards of education and "life expectations" of average workers were the outcome of "adequate housing, food and health care"29 can make one wonder if the author is really aware of how the reality of socialist countries looked like.

\subsection{Difficulties concerning transformation in Post-Socialist countries}

The specificity of Post-Communist countries derives from the fact that their economies are in the process of transformation into capitalism. Therefore, to achieve their goal, they usually have to compromise on many aspects, because of the lack of proper

25 D. Bohle, B. Greskovits, Capitalist Diversity..., p. 8; C. Lucian, Europeanization, Varieties of Capitalism, and Economic Performance in Central and Eastern Europe, New York 2006, p. 23.

26 D. Lane, "Post-State Socialism”..., p. 13. It is important to emphasize that although the democratisation and the economy transition were not simultaneous, the reason for that lies in the fact that the reforms required time, not in the intentions of the reformers. L. Balcerowicz, Socjalizm, kapitalizm, transformacja. Szkice z przetomu epok, Warszawa 1997, pp. 172-173.

27 D. Bohle, B. Greskovits, Capitalist Diversity..., pp. 61-62.

28 D. Lane, "Post-State Socialism”..., p. 20.

29 Ibid., p. 21. 
ideology or capitalists and entrepreneurs. Lane then stresses that to analyze those countries properly, it is not only important to define the type of capitalism, but the scale of capitalism implementation as well. Knowing that the tradition of state-planning and low-wage employment might have affected the outcomes of the introduction of capitalism, the author considers a couple of aspects to be important for the analysis of the extent to which capitalism is present in socialist countries: the existence of a free market and liberalization of prices, the accumulation of capital, the scale of private ownership of assets, connection to global economy, frameworks for the coordination of companies, as well as the level of inequality and redistribution of incomes ${ }^{30}$.

While analyzing the transformation in former Communist countries Lane notes that the Western economists who were advisors in the Post-Communist states during their transformation were convinced that the fall of the Soviet Union left those countries without political and ideological burdens. With this idea in mind, and treating Post-Communist societies as a tabula rasa, they proposed to implement the Anglo-American type of capitalism in three steps: creating the free market stimulating competition and creating conditions enhancing competitiveness, denationalization of the state properties, and dealing with the effect of unemployment and poverty as short-term consequences of the reforms ${ }^{31}$. In fact, the processes happening in the Post-Communist countries were far more complicated. Along with the creation of institutions like the financial markets, the existing ones had to be transformed to comply with new standards; unfortunately, the influence of those two processes' interactions was not yet discovered ${ }^{32}$.

The introduction of the neoliberal concept of capitalism meant the focusing on private property as an indispensable element of the creation of a capitalist class and increasing sales as well as profitability of capital. As Lane's survey shows, the Post-Communist countries can be divided into three groups depending on the level of privatization and the share of GDP belonging to the private sector. The Czech Republic, Hungary, Lithuania, Poland, and Slovakia fall into the first category, with the highest extent of privatization and private sector share in GDP. The middle category is comprised of Albania, Armenia, Bulgaria, Croatia, Georgia, Kirgizia, Latvia, Macedonia, Romania, Russia, Slovenia and Ukraine. The lowest outcomes can be observed in Azerbaijan, Belarus, Bosnia, Moldova, Tajikistan, Turkmenistan, Uzbekistan and former Yugoslavia ${ }^{33}$.

As Lane concludes, the transformation which started in the 90s has led most countries to capitalism, although it is debatable to what extent capitalism was implemented. All of the Post-Communist countries still differ from market capitalism countries because of the high level of state engagement in the economic processes and the low level of stock market capitalization. Also, the extent of internal investment is

\footnotetext{
Ibid., p. 21.

31 Ibid., pp. 21-22.

32 P. Baboš, "Varieties"..., p. 445.

33 D. Lane, "Post-State Socialism”..., pp. 22-23.
} 
very low, which puts those countries behind Western capitalist states. Foreign direct investments (FDI), on the other hand, are more developed, achieving higher position than middle-income countries, especially in: Bulgaria, Croatia, the Czech Republic, Estonia, Georgia, Hungary, Kazakhstan, Latvia, Lithuania, Moldova, Poland, Romania and Slovakia. However, since the privatization process is coming to an end, the amount of FDI consequently decreases ${ }^{34}$.

Most of the differences inside the Eastern Bloc are in the area of the "heartland" of the former USSR and East Central Europe (already a part of European Union), which are better at coping with changes introduced during the transformation and currently are dealing with less income inequality. Lane came up with two different categories of the Post-Communist countries. The first one, closest to the continental type of capitalist countries, consists of some of the new EU members from East Central Europe: the Czech Republic, Estonia, Hungary, Poland, Slovakia and Slovenia. They have introduced high levels of privatization and marketization, and their part in the global economy is quite formidable. However, the stock capitalization is still insufficient, and rather than the stock exchange, the state is the main power in economic coordination. Bulgaria, Croatia, Latvia, Lithuania and Romania, as a kind of a subgroup, are characterized by an even higher role of state in coordination as well as lower levels of privatization in comparison to the previously described group. All of them, thanks to the challenges discerned by the European Union and the International Monetary Fund, have achieved most of the other requirements of capitalism and created not only an economic basis, but class structure, civic society, and an accurate governmental system as well. The second type of capitalism that arose in the Post-Communist area is, according to Lane, a hybrid state/market uncoordinated capitalism. It consist of Russia, Ukraine, Kazakhstan, Georgia, Turkmenistan and Moldova, where there is still a high level of poverty, unemployment and income inequality. Integration with the global market in those countries is still insufficient and they display a low level of domestic investment. The lack of cultural and psychological background for capitalism is very visible, even though those countries introduced privatization and market monetary exchange ${ }^{35}$.

\section{APPLICABILITY OF THE VOC IN EAST CENTRAL EUROPE}

The Varieties of Capitalism theory, introduced as an easily understandable framework for surveying developed capitalism and providing clear categories for comparison of different types, became very popular among Western scholars. But although the approach was created on the basis of examples from Western Europe, USA and Japan, academics started applying it to other countries as well, hoping that it could be used as a tool not only in the "Western core", but also in more general, global context ${ }^{36}$. Yet

\footnotetext{
34 Ibid., pp. 23-34.

35 Ibid., pp. 35-36.

36 A. Nölke, A. Vliegenthart, "Enlarging the Varieties”..., pp. 670-671.
} 
the survey created for Post-Communist countries had already shown that there are too many differences between particular countries or groups of countries to include them into one of the previously created categories ${ }^{37}$, and that most scholars still question the development level of capitalism in those countries ${ }^{38}$. This led scholars to introduce "mixed" or "hybrid" types of capitalism in an attempt to capture the specificity of the surveyed area, but as Nölke and Vliegenthart have shown, all those attempts have failed ${ }^{39}$.

\subsection{The idea of Dependent Market Economy}

In contrast to previous studies on the subject, Nölke and Vliegenthart proposed to create a new category in the Varieties of Capitalism approach. Focusing on the East Central European countries (the Czech Republic, Hungary, Poland and Slovakia), the scholars claim that traditional approaches may lead to misunderstanding and confusion, since some surveys place this group of countries in the Liberal Market Economy type, others in the Coordinated Type, and some described it as a combination of both. Seeing the insufficiency in this approach, Nölke and Vliegenthart introduced the category of Dependent Market Economy, which would better characterize East Central European countries. In short, thanks to cheap, yet skilled human resources, transfering the technology, know-how as well as the capital inflows and foreign direct investment, dependent market economies produce consumer goods that can be described as relatively complex and competitive ${ }^{40}$.

The scholars claim that this theory is also the answer to the critique on the Varieties of Capitalism approach, such as strict dualism of the theory or its focus on the core Western world. The other weakness that the authors wanted to avoid was the underestimating of the role of transnational companies and the influence of transnational actors on the economies in East Central Europe in general, which is the tendency in the traditional approach. In fact, the label "dependent" is a result of the conviction that East Central European economies rely on the foreign capital much more than countries considered to be Liberal or Coordinated Market Economies ${ }^{41}$.

The argument of Nölke and Vliegenthart is based on the conclusion from the recent literature on the subject, regarding the relations between transnational companies and the different kinds of capitalism. Transnational corporations are said to look for relatively cheap and skilled labor force with the sufficient knowledge of technology. The Dependent Market Economies, possessing that kind of human resources, have an advantage in attracting the transnational corporations' attention. A drastic change in

\footnotetext{
D. Lane, “Post-State Socialism”..., pp. 13-62.

P. Baboš, "Varieties”..., p. 444.

39 D. Bohle, B. Greskovits, Capitalist Diversity..., p. 11; A. Nölke, A. Vliegenthart, "Enlarging the Varieties"..., p. 671.

40 A. Nölke, A. Vliegenthart, "Enlarging the Varieties"..., pp. 672-673.

41 Ibid., p. 673.
} 
socioeconomic institutions, caused by the collapse of command economy, has also played a pivotal role in attracting foreign interest. Because the political leaders were forcing rapidity in developing the economic system and the region was lacking a domestic class that could create a framework for new institutions, the transnational corporations have found a suitable place for lobbying their preferences. Considering that in the Liberal Market Economies the main coordination mechanisms were formal contracts and competitive markets, and in the Coordinated Market Capitalism - non-formal networks between economic actors, the authors propose a hierarchy in between transnational corporations as a central coordination mechanism in Dependent Market Economies. An analysis of the complementariness of the hierarchy of transnational corporations (as a corporate governance element of the Variety of Capitalism approach) and other institutions important for the Variety of Capitalism theory shows that the competitiveness of the Dependent Market Economies lies on a highly advantageous base for establishing the FDI. East Central Europe can compete in the global market thanks to a skilled, low-cost labor force and attractive conditions for investors, even if the radical and incremental innovations typical of Liberal and Cooperative Market Economies are not getting transferred to the Dependent ones ${ }^{42}$.

\subsection{Institutions of Dependent Market Economies}

To clearly describe the main institutions of Dependent Market Economies and the features which differentiate them from Liberal and Coordinated Market Economies, Nölke and Vliegenthart re-established the framework introduced by Hall and Soskice and created a comparison of the main characteristics of the seven institutions that they have found sufficient for the typology. As mentioned before, in terms of coordination mechanism, the DME are based on transnational companies and their inner hierarchies, while in the LMEs it consists of competitiveness and formal agreements. The main mechanism in the CME, on the other hand, can be characterized by the networks between the firms. In case of a second institution, raising capital in the state, the DME are dependent on foreign investments or funds generated from banks that are owned by foreign investors (the CME: funds raised domestically/internal banks; the LME: stock markets). The corporate governance of the DMEs is driven by the hierarchy of transnational corporations. It is mostly the result of privatization policy during transformation, which have led to many take-overs by foreign companies (the LME: dispersed shareholders; the CME: concentrated shareholders). In the DME, instead of negotiations between shareholders and managements, as it would be in other market economies, the main negotiations are held between headquarters and branch managers. It emphasizes the region's dependency, because transnational enterprises tend to own many small and medium companies in the region, connecting them to the Western market and influencing their behavior ${ }^{43}$.

$\begin{array}{ll}42 & \text { Ibid., pp. 676-679. } \\ 43 & \text { Ibid., pp. 679-684. }\end{array}$ 
Industrial relations in the DME are the middle ground between the LME (pluralist markets, employee management) and CME (sector-wide consensus) which invites foreign investors interested in a relatively low cost. The next institution, education and training system, limited in the DME as a consequence of constantly decreasing funds for that cause since 1990s and vocational training, is designed to meet the expectations of transnational corporations (CME: employers' investment in the workforce; LME: high levels of research and development skills). In the case of innovations, the DME are far behind the other two varieties, mostly because of their dependency. Funding of research and development is limited to the most basic needs concerning short-term increased profit of the company. Because East Central European countries are seen as places for production instead of research, most of the innovations are also imported from the outside instead of being developed in the region. Technology and know-how is implemented under strict control of transnational companies headquarters ${ }^{44}$.

Comparative advantages of the DME is a specialization in export industries that requires a skilled, cheap labor force. The model presented here seems to be stable and effective. Although in the long run it might face difficulties, for now it is considered relatively successful, especially while taking into account the challenges of the transition from communism to capitalism. As the authors emphasize, the current dependency on foreign investments is not profitable for the entire population of the DMEs, but creates a gap between the participants of the export-oriented trade industries and the non-export-oriented ones. The analysis shows that to stabilize the situation in East Central Europe and to avoid the potential erosion of the system, those countries should start investing in education and research to balance the structure of labor and industries ${ }^{45}$.

The development of the VoC prepared by Nölke and Vliegenthart deserves further research. To set the base for the new element in Hall and Soskice's approach on transational companies and their influence - the Dependent Market Economy - was very innovative and in fact took into consideration the contemporary economic issues ${ }^{46}$. Yet, although in their theory, Nölke and Vliegenthart were trying to avoid most of the criticisms that the original Varieties of Capitalism approach had attracted, but in the end their efforts were insufficient. By focusing only on the Czech Republic, Hungary, Poland and Slovakia, the authors left a lot of countries from the European part of the former Soviet Bloc without any comment. Dorothee Bohle and Bela Greskovits' criticism also addresses the insufficiency of concepts concerning the difficulties in creating the market in post-Socialist countries. Those scholars notice that the transformation from state-controlled economy to the free market has just recently finished and that the currently invisible, far-reaching outcomes of all the reforms should not be underestimated $^{47}$.

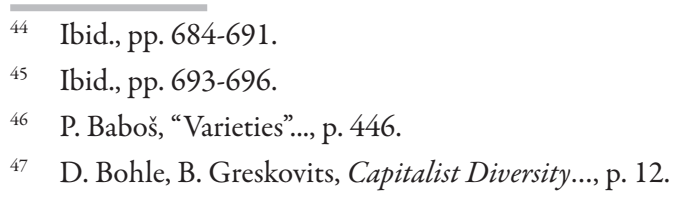




\subsection{Neoliberal, embedded neoliberal and neocorporatist capitalism in East Central Europe}

To properly address the complexity of the region, the authors treated East Central Europe very broadly and divided it into groups: Baltic countries (Estonia, Latvia, Lithuania), the Visegrad group (Poland, the Czech and Slovak Republic, Hungary), former Yugoslavia (Bulgaria, Romania and Croatia) and Slovenia. Each of the groups is said to have chosen different ways of introducing the free market economy after 1989. The scholars named three types of capitalism in the region: neocorporatist in Slovenia, neoliberal in the Baltic states, and embedded neoliberal in the Visegrad countries $^{48}$.

The post-socialist countries, in an attempt to introduce capitalism after the end of the Cold War, became part of a wide, complex global economy which made the boundaries of public authority unclear and vague because of the global competitive imperative, making it practically impossible for governments to protect their societies ${ }^{49}$.

According to the authors, the embedded neoliberal capitalism, which is said to concern the Visegrad countries, is characterized as "a permanent search for compromises between market transformation and social cohesion in more inclusive, but always efficient system of democratic government" ${ }^{\prime 50}$. Nevertheless, during the transformation, the Visegrad countries tried to protect their citizens by introducing compensation for transformation costs to domestic companies and finding resources to attract transnational corporations. This desire to lessen the negative outcomes of transformation and social cohesion is said to be distinctive for neoliberal capitalism in the Visegrad countries and characterizes them as "embedded". These compensations for the cost of transformation were one of the two popular paths that were followed in the face of the challenges of the marketization in the region ${ }^{51}$.

The neoliberal capitalism that arose in the Baltic states can be then characterized by a low (if not the lowest) level of social protection, strict fiscal policy as well as a low rate of growth of industrial production and a low level of complex products' output. The opposite neocorporatist in Slovenia is described by the authors as a system with a high social protection; the least radical, and with relatively high level of complex exports ${ }^{52}$. In the comparison between Estonia and Slovenia prepared by F. Adam, P. Kristan and M. Tomšič, the former is considered to have the highest level of social inequalities, while the latter can be placed among the EU countries with lowest level ${ }^{53}$. While analy-

48 Ibid., pp. 1-3.

49 Ibid., p. 17; J. Wilkin, Jaki kapitalizm..., pp. 106-107.

50 D. Bohle, B. Greskovits, Capitalist Diversity..., pp. 1-3.

51 Ibid., p. 22.

52 P. Baboš, "Varieties"..., p. 448.

53 F. Adam, P. Kristan, M. Tomšičc, "Varieties of Capitalism in Eastern Europe (with Special Emphasis on Estonia and Slovenia)", Communist and Post-Communist Studies, vol. 42, issue 1 (2009), [online] http://dx.doi.org/10.1016/j.postcomstud.2009.02.005. 
zing the 20 years of transformation in the region (between 1989 and 2007), Bohle and Greskovits have discerned three main periods: opening, regulating and stabilizing capitalism. The first half of this time, up until 1998, is considered to be a period of major decisions and reforms toward shaping the new political economies. The authors describe the next one as a time of consolidation of the new institutions. Using the data from the European Bank for Reconstruction and Development (EBRD) Bohle and Greskovits calculated the countries' output in opening and regulating markets ${ }^{54}$. In comparison to the radical Baltic states and the very cautious Slovenia, the authors place the Visegrad countries in between. The authors point out that radicalism of the Baltic states was a result of the struggle to catch up with the countries where some liberalizing reforms were introduced before 1989 - reforms which helped those countries, especially Poland and Hungary at the beginning of transition ${ }^{55}$, even though, as Bohle and Greskovits notice, scholars usually underestimate or even ignore the fact that good results in the first years of transformation in those countries were the outcomes of reforms implemented in Communist times ${ }^{56}$.

\subsection{The importance of the European Union}

Bohle and Greskovits are the first scholars who applied the VoC theory and acknowledged the great impact of the European Union and its regulations on the shaping of capitalism in East Central European countries. The integration with the European Union economies was not only an opportunity to develop the fragile new markets, but also a challenge, because of the regulations and norms the post-socialist countries wanted to adopt. This race towards the EU was an element of greater, regional policies of "leaving the East" and "returning to Europe". The EU was then generally viewed as a positive power, because the possibility of membership was motivating political leaders and whole countries to work toward reforms. The fact that the EU was supporting the institutional and administrative development is also an advantage of close relations between ECE and the EU. The accession to the EU greatly helped in stabilizing the poli-

54 Unfortunately, the authors do not explain the methods of this calculation. The conclusions Bohle and Greskovits present are disturbing if we take into consideration that Poland is generally considered as the country that implements the most radical reforms. L. Balcerowicz, Socjalizm..., p. 372.

55 Although Bohle and Greskovits rightly observed that the reforms before the 1989 had an important impact on some countries of the region, their theory misses important details. In the beginning of the 90s Poland was facing many problems, for example a high level of dependency from the Soviet market, macroeconomic inequalities, hyperinflation, a gigantic foreign debt, lack of qualified specialists in economy and finances, great influence of the trade unions on state policy and many more. L. Balcerowicz, Socjalizm..., pp. 356-360. The starting point for Poland, then, was not as good as Bohle and Greskovits seem to think. The radical reforms implemented in Poland at the beginning of the transition had very good results and inspired other countries of the region. The radicalness of the reforms in the Baltic states was an effect of previous tardiness. J. Kaliński, "Ocena wyników transformacji: Polska na tle krajów w regionie”, in K. Żukrowska (ed.), Transformacja systemowa w Polsce, Warszawa 2010, pp. 563-564.

D. Bohle, B. Greskovits, Capitalist Diversity..., pp. 25-27. 
tical status quo in East Central Europe and provided those countries with institutional advantages that attracted international investors ${ }^{57}$.

The Visegrad countries in particular have established policies to attract transnational corporations by providing an attractive foundation for establishing production, which lead this group to become one of the biggest export industries. They were also providing help for the part of the society that was considered "non-productive" as a social protection policy. Based on the prepared surveys, Bohle and Greskovits predict that the stability of embedded liberalism as is now established in the Visegrad countries is likely to change under the impact of future variables. Pressure from global and European actors, rivalry among neighboring states as well as democratic competition might severely impact the political economies in this group ${ }^{58}$.

\section{CONCLUSION}

The review of the Varieties of Capitalism theory development has shown that improvement of this approach continues. Scholars try to address the issues in the most multidimensional ways to achieve full objectivity and complexity. The need to define clear indicators for comparison of different capitalisms seems strong, yet it is impossible to be satisfied.

Each variable of the Varieties of Capitalism theory provides a different framework for analyzing the situation of a particular country and it is hard to decide which - or even if - any of the approaches is insufficient or faulty. Hall and Soskice provide the traditional, widespread concept which introduces a clear division and allows scholars to produce a mixed version for the countries outside the core. Amable is more specific, although he also limits his typology to the core and Asian countries. Nölke and Vliegenthart, on the other hand, introduce an interesting variation of the traditional VoC approach, which had already become well known. However, because of the narrow scope, its applicability it is quite limited.

On the other hand, Bohle and Greskovits' publication, although covering in detail the broad subject of establishing political market economies in the entire East Central Europe, fails to provide a clear approach to the Varieties of Capitalism theory. Vast arrays of countries and countless institutions that are described and analyzed make the approach blurry and too complex to actually shed some light on the major differences across the region, or between the region and the Western core. It seems as if the authors want to touch upon too many aspects and present the outcomes of their analysis in a complicated way, constantly trying to compare all the countries, which introduces unnecessary chaos. However, it is by far the most complex analysis of the transformation in the region.

While trying to find a place for East Central Europe in the different approaches to the Varieties of Capitalism theory, I have discovered that there is no such thing as

\footnotetext{
57 Ibid., pp. 56-57, 85-86, 94.

58 Ibid., pp. 138-139.
} 
a "place". An analysis of each version of the theory shows that the categorization is doomed to faultiness, and yet that it is not a failure. By focusing on different elements of the established capitalisms in East Central Europe instead of giving a clear answer, the theories present diverse visions of the area with respect to the dimensions we consider the most important. From this point of view they are not providing a universal answer but rather, as all theories, try to introduce some order into the world as we perceive it.

\section{REFERENCES}

\section{Books:}

Reference literature:

Hall P., Soskice D., "An Introduction", in P. Hall, D. Soskice (eds.), Varieties of Capitalism. The Institutional Foundations of Comparative Advantage, Oxford 2001.

Auxiliary literature:

- monographs:

Albert M., Kapitalizm kontra kapitalizm, Kraków 1994, Zrozumieć Kapitalizm.

Amable B., Diversity of Modern Capitalism, Oxford-New York 2004.

Balcerowicz L., Socjalizm, kapitalizm, transformacja. Szkice z przetomu epok, Warszawa 1997.

Bohle D., Greskovits B., Capitalist Diversity on Europe's Periphery, Ithaca 2012.

Esping-Andersen G., The Three Worlds of Welfare Capitalism, Princeton 1990.

Lucian C., Europeanization, Varieties of Capitalism, and Economic Performance in Central and Eastern Europe, New York 2006.

Wilkin J., Jaki kapitalizm, jaka Polska?, Warszawa 1995.

- chapters in collective works:

Gładys-Jakóbik J., "Kryzys kapitalizmu, wartości etycznych czy współczesnej kultury?”, in J. Osiński (ed.), Kapitalizm czy kapitalizmy? Anatomia i ewolucja formacji, Warszawa 2012. Jarosiński K., "Sektor publiczny wobec transformacji systemowej w Polsce”, in J. Osiński (ed.), Kapitalizm czy kapitalizmy? Anatomia i ewolucja formacji, Warszawa 2012.

Kaliński J., "Ocena wyników transformacji: Polska na tle krajów w regionie", in K. Żukrowska (ed.), Transformacja systemowa w Polsce, Warszawa 2010.

Lane D., "Post-State Socialism: A Diversity of Capitalism?", in M. Myant, D. Lane (eds.), Varieties of Capitalism in Post-Communist Countries, Basingstoke-New York 2007.

Mykhnenko V., "Poland and Ukraine: Institutional Structures and Economic Performance", in M. Myant, D. Lane (eds.), Varieties of Capitalism in Post-Communist Countries, BasingstokeNew York 2007.

Sztaba S., "Ewolucja kapitalizmu i teorii ekonomii", in J. Osiński (ed.), Kapitalizm czy kapitalizmy? Anatomia i ewolucja formacji, Warszawa 2012. 
- articles in scientific journals:

Adam F., Kristan P., Tomšič M., "Varieties of capitalism in Eastern Europe (with special emphasis on Estonia and Slovenia)", Communist and Post-Communist Studies, vol. 42, issue 1 (2009), [online] http://dx.doi.org/10.1016/j.postcomstud.2009.02.005.

Baboš P., "Varieties of Capitalism in Central and Eastern Europe: Measuring the Co-ordination Index of a National Economy", SEER Journal for Labour and Social Affairs in Eastern Europe, no. 4 (2010).

Nölke A., Vliegenthart A., "Enlarging the Varieties of Capitalism: The Emergence of Dependent Market Economies in East Central Europe", World Politics, vol. 61, no. 4 (2009), [online] http://dx.doi.org/10.1017/S0043887109990098.

Török A., "Newcomers in the Developed World? Notes on the Varieties of Capitalism in the New Member States of the European Union", International Journal of Business Insights and Transformations, vol. 5, no. 3 (2012).

Julita DUDZIAK, studentka stosunków międzynarodowych (I rok studiów II stopnia) i kulturoznawstwa (III rok, specjalizacja: studia dalekowschodnie) na Uniwersytecie Jagiellońskim w Krakowie. Od 2009 r. jest członkiem Ośrodka Praw Człowieka UJ, a od 2011 r. Koła Studentów Stosunków Międzynarodowych UJ oraz Dalekowschodniego Koła Naukowego UJ. Odbyła staż w Wydziale Konsularnym Ambasady RP w Berlinie. Stypendystka programu Sokrates/Erasmus i międzynarodowej wymiany „EU-Australia Border Crossing: People And Places". 